\title{
IMPACT OF JABAL KELOR DEVELOPMENT AS A TOURISM ATTRACTION
}

\author{
Steviani Batti ${ }^{1}$, Dhimas Setyo Nugroho ${ }^{2}$, Andi Lopa Ginting ${ }^{3}$, Herry Novrianda ${ }^{4}$ \\ steviani@ecampus.ut.ac.id ${ }^{1}$, dhimas.nugroho@ecampus.ut.ac.id ${ }^{2}$, andi.lopaginting@ecampus.ut.ac.id ${ }^{3}$, \\ herry.novrianda@ecampus.ut.ac.id ${ }^{4}$ \\ a,b,c,dProgram Studi S1 Manajemen, Fakultas Ekonomi, Universitas Terbuka, Indonesia
}

\begin{abstract}
Jabal Kelor tourism development has triggered a positive impact on the residents of the Dadap Kulon hamlet. The purpose of this study is to present an analysis of the impact of community-based tourism development in Jabal Kelor. In this study, semi-structured interviews were conducted with key informants involved in developing Jabal Kelor. Observation and documentation to check the validity of the data. Interactive data analysis techniques take place continuously until complete until the data is saturated. The results showed that the Dadap Kulon community felt a positive impact on the development of Jabal Kelor as a tourist attraction. The positive impact can be seen from the economic, environmental, social, and political aspects. Namely, the emergence of new jobs increased income and allocation of funds for tourism development. Regional carrying capacity and waste disposal management. Improvement of the quality of life and pride of the community. Activating community participation and building a management system.
\end{abstract}

Keyword: rural tourism, impact of tourism, Jabal Kelor

\section{INTRODUCTION}

Indonesia is one of the countries that are intensively conducting tourism development. Various provinces in Indonesia are competing to develop tourist destinations. Yogyakarta Special Region is one of the provinces in Indonesia, which is developing various tourist destinations. Yogyakarta Special Region has the vision to realize itself as one of the world-class destinations, competitive, culturally oriented, sustainable, and able to encourage regional development and community empowerment. To realize this vision, Yogyakarta Special Region has established 11 tourist areas, which will be the main focus in tourism development. The entire tourist area is spread over five administrative regions in DIY with the aim of equitable regional development and equitable distribution of community empowerment [1]. Jabal Kelor is a hilly area that is a new tourist destination in Dadap Kulon, Bawuran, Pleret, Bantul, Yogyakarta Special Region. Jabal Kelor emerged as a result of the indirect impact of the vision of tourism development in the Special Region of Yogyakarta. Jabal Kelor is a tourist destination in the form ofa hill that can offer natural scenery from a height. Consists of 2 peaks, namely the peak of Gebang and Sosok.

Jabal Kelor is one of the new tourist destinations located in Dadap Kulon, Bawuran Village, Pleret District, Bantul Regency, Yogyakarta Special Region Province. The destination is a hill that offers a natural view from a height. Consists of 2 peaks, namely the peak of Gebang and the peak of Figure. The distance from the top of Gebang to Puncak Sosok is approximately $1 \mathrm{~km}$, with steep and rocky road conditions. Besides, there is the Gebang Bike Park, which is a mountain bike crossing path for tourists who like this sport. Both of these peaks began to be known since 2016, the beginning of the development of this destination came from the habits of young women who made Dadap Kulon a gathering place to celebrate the New Year.

With the increasing number of visitors arriving, residents try to design the Dadap Kulon as a tourist attraction named Puncak Gebang. The name "Gebang" is taken from the name of the tree that grows at the foot of the Dadap Kulon hill, which is the Gebang Tree. The word 'Jabal' is taken from its place at the peak. The hard work of young people and assisted by the Dadap Kulon community, Puncak Gebang, became a broader and cleaner area through the community service program every Sunday.

Bawuran is one of the villages in Pleret District, Bantul Regency, Yogyakarta Special Province. Bawuran village is located in a hilly area with a steep road so that motorized vehicles are still challenging to reach this area. Besides the lack of living facilities for residents to get clean water and electricity. The tourism destination Jabal Kelor has not yet been arranged so that the participation of the Bawuran community is needed. Residents hope that by building the Jabal Kelor can improve their quality of life. Apart from Jabal Kelor, many rural communities in developed and developing countries, as well as in small island countries, have adopted alternative forms of tourism 
as the most viable option for sustainable economic, socio-cultural and environmental development [2].

Community-based tourism is centered on the involvement of local communities in the planning and management of tourism development to create a more sustainable industry. So that people are taught to manage tourism destinations [3]. Community-based tourism is intended as a tool for community development and environmental conservation. For this purpose, it must be seen thoroughly about aspects that can have an impact on the community, such as social, cultural, economic, environmental, and political aspects. Understanding the community situation can maximize the capacity of community- based tourism to be more productive and sustainable for community development [4].

Community-based tourism management has provided benefits in the economic aspects of economic growth. Community-based tourism in the Khama Rhino Sanctuary Trust, Central District, Botswana has increased the number of tourists visiting so that new job vacancies, both permanent and part-time jobs, have emerged [5]. Besides that, one of the multi-ethnic villages in Viscri, Romania, also experienced the same thing where community-based tourism had a positive impact. Communities can provide goods and services needed by tourists such as lodging, traditional products, and local food [6]. So that they can overcome the limitations of capital and can turn the wheels of the economy [7].

People who already know each other, have the same background and have experienced periods of the same change will form a personal bond and solidarity to work together to achieve a common goal [8]. In addition to reinforcing a sense of solidarity, people get many new relationships that can bridge the outside world with the community so they can work together without regard to status to foster a sense of tolerance [6]. Besides the increasing number of tourist visits, resulting in the community indirectly must learn about environmental management for long-term sustainability [5]. Proper management can be realized with specific rules agreed upon by citizens for the sake of sustainable management, security, and environmental sustainability [9]. Communities work together to develop tourism, which in turn makes them build and change circumstances in a positive direction while protecting the environment [10]. In this case, tourism acts as a catalyst, through collective action, the community realizes that their various efforts to pursue positive change. These efforts were emphasized through community meetings and organizational formation, so that solidarity became stronger. Community- based actions play an essential role in the long-term success of tourism development [10].

The same thing also happened in Jabal Kelor, various activities have been carried out, but that does not mean the construction of the tourist destination has been completed. The development of this destination has just begun and is a task for all competent elements in developing Jabal Kelor. Many infrastructure facilities must be fulfilled; therefore, various methods are carried out, such as providing village development fund boxes, community service, and finding new sources of funds, continue to be carried out in order to meet adequate infrastructure. The purpose of this paper is to present an analysis of the impact of Jabal Kelor tourism development.

\section{METHODS}

The methodology used for this research investigation is based on field research conducted with semistructured interviews, observations, and documentation. Interviews were conducted to find out and analyze the state of tourism, a picture of community participation, forms of community participation, and the results of community participation. Semi-structured interviews were conducted with key informants such as the chairperson and several tourism-aware community members (POKDARWIS), the village head of Bawuran, and several residents. Observation, documentation, and analysis of local newspapers carried out as support for triangulation. The study was conducted from November 2017 to January 2018. Data collected through interviews, observations, documentation was then processed and presented in the discussion using interactive data analysis and continued continuously until completion, so that the data was saturated [11]. Activities in interactive data analysis, consisting of data reduction that is summarizing, choosing the main things. The next process is the presentation of data in the form of the description so that the data can be understood easily. The last step is verification in the form of drawing conclusions and verification supported by valid evidence and coefficients when the researcher returns to the field to collect data, then the conclusions put forward are credible conclusions.

\section{RESULTS AND DISCUSSION}

Jabal Kelor is located in the hamlet of Dadap Kulon, Bawuran Village, Pleret District, Bantul Regency, Special Province of Yogyakarta, Indonesia. Jabal Kelor is a new tourist destination consisting of Gebang Peak, Puncak Sosok, and Gebang Bike Park, which is a mountain bike track. Tourist attractions offered at these two peaks are viewing natural panoramas and watching significant events together. In addition to sports, tourism lovers can do mountain bike racing training at Gebang Bike Park. Jabal Kelor can be visited by tourists from 5 am to $1 \mathrm{pm}$. Entrance fees and 
fees for using the bike track are still voluntary. Some of the impacts of the development of Jabal Kelor as one of the tourist destinations can be seen from several aspects, namely economic, environmental, social, political aspects.

\section{Economic Aspects}

Jabal Kelor, which is managed by the community, has had a positive impact, with the increasing number of tourist arrivals along with the increase in tourist spending. Spending is realized from parking services, food, and beverage consumption, hall rental fees, mat rental fees, toilet cleaning fees, bicycle track rental fees, and voluntary funds from tourists. In addition to providing additional income, an increase in the number of tourists also results in the emergence of new jobs as part-time workers. Part-time jobs in Jabal Moringa such as being a waiter at a place to eat, parking attendants, security officers, ticket officers, janitors. Even though these jobs are part-time jobs, they have provided additional income to the community. Some residents also have a lot to sell in the Jabal Kelor area where they provide goods and services needed by tourists, so they can increase income and overcome the limitations of venture capital. At present, most of Jabal Kelor's tourist destination revenue has been allocated for the construction of additional tourist facilities and attractions. The manager hopes that with this much development, it will attract even more tourists.

\section{Environmental Aspects}

Jabal Kelor is located in the Dadap Kulon hamlet, a remote hamlet where there are minimal access and facilities. The quality of the road to get to the village is also inadequate because the road is quite steep. After the community built facilities and infrastructure at the Jabal Kelor tourist destination, many tourists visited. Gebang Peak is the first tourist attraction built by the community as well as triggering the community to build other facilities. After building Puncak Gebang, the community worked together to build a road from Puncak Gebang to Puncak Sosok using existing funds, both from contributions and income from the management of Puncak Gebang. After the community works together to build a road, the quality of the road users will be better. In order to support the safety and comfort of tourists, the community added some lights to light the streets at several locations. The community built several facilities such as small stalls and halls for rent to tourists in Puncak Sosok. The manager also built a mosque, toilets, and provided several chairs and tables to add to the comfort of tourists.

\section{Social Aspects}

Improved quality of life is slowly emerging. People who initially made a living as farmers and farmed as economic support has tried to earn extra income by selling in the Jabal Kelor area and working part-time. Besides improving the quality of life. Jabal Kelor's development also increases people's sense of pride. Jabal Kelor was once the location of the Mountain Bike Racing National Championship held by the Yogyakarta Special Region Police in 2017. By holding this event, citizens increasingly believe that through the development of Jabal Kelor, their quality of life will improve. Jabal Kelor is currently one of the favorite places for tourists who love mountain bike racing.

In the development of Jabal Kelor tourism destinations, almost every element of citizens have their respective roles in management. Youth group as the spearhead of management. The women's group participated in selling food; the men's group helped and directed the youth group in managing Jabal Kelor. Social ties among community members provide space to share the same values and feelings. The community cooperates in developing tourism, which in turn makes them build and discover their community's identity as Jabal Kelor society.

\section{Political Aspects}

At the beginning of management, Dadap Kulon sub-village consisting of 4 community groups jointly managed Jabal Kelor, but over time, the majority of those managing came from just one community group. Managers allow the involvement of people outside the village of Bawuran who want to contribute to the development of Jabal Kelor. Residents from 3 other community groups also did not mind this.

At present, the development of Jabal Kelor has activated community participation. The community held deliberations and decided to form an organization that gave the command in managing Jabal Kelor. The organization that takes care of the management of Jabal Kelor is called a tourism-conscious community group (POKDARWIS). A group of youths manages Jabal Kelor from Dadap Kulon hamlet. Members' deliberations are held once every 35 days. The tourism-aware community structure (POKDARWIS) in Jabal Kelor consists of a chairperson and deputy, two secretaries, two treasurers, and sixteen different divisions of which almost all of the members are Dadap Kulon youths. These divisions are 1) Accommodation division, 2) Artistic, 3) Funds and Business, 4) Media and Publications, 5) Guiding, 6) Public Relations, 7) HR Development, 8) Cleanliness and Health, 9) Arts, 10) Consumption, 11) Marketing, 12) Tourism Development, 13) Equipment, 14) Agriculture and Plantation, 15) Transportation, 16) Licensing and Security. With the division of divisions in the management of 
Jabal Kelor, the community hopes that the development of Jabal Kelor will be better and faster because the main tasks of each division are precise

\section{CONCLUSION}

Through the development of Jabal Kelor as a tourist attraction, the Dadap Kulon village community has felt its positive impact. The economic impact is manifested by the existence of new jobs, increased community income, and the emergence of funds allocation for the development of Jabal Kelor. As a result of the emergence of funds from the management of Jabal Kelor, the community can carry out road construction, which then triggers the emergence of the construction of other facilities for tourists. Residents can also utilize facilities built for tourists. In order to maintain mutual comfort, the manager has agreed on a policy to deal with several issues regarding waste management, tourist visiting hours, division of management division, and revenue management. Various facilities and infrastructures that were built in Jabal Kelor indirectly have improved the quality of life of the community. The pride of the community is also evident in the success of residents managing the Mountain Bike Racing National Championship. All of this development can be done through active citizen participation and a management system that has been created by residents. 


\section{REFERENCES}

2013. Pengembangan Wisata, Bappeda Daerah Istimewa Yogyakarta, (Online), http://bappeda.jogjaprov.go.id/jogja_masa_depan/detail/Pengembangan-Wisata.

Ahebwa, W.M., Aporu, J.P. and Nyakaana J.B. 2016. Bridging community livelihoods and cultural conservation through tourism: Case study of Kabaka heritage trail in Uganda. Tourism and Hospitality Research, vol. 16, no. 2, Page 103-115.

H. H. Javier. 2013. Community Development through Tourism Opportunities and Challenges in Burdeos, Philippines. The Hong Kong University School of Hotel and Tourism Management

Huang, Y.H. and Stewart, W.P. 1996. Rural tourism development: Shifting basis of community solidarity. Journal of Travel Research, vol. 34, Page 26-31.

Hwang, D., Stewart, W.P. and Ko, D. 2012. Community Behavior and Sustainable Rural Tourism Development. Journal of Travel Research, vol. 15, no. 3, Page 328-341.

Lorio, M., Wall, G. 2014. Community-based tourism and networking: Viscri, Romania," Journal of Sustainable Tourism, vol. 22, no. 2, Page 234-255.

Mbaiwa, J.E. and Stronza, A.L. 2011. Changes in resident attitudes towards tourism development and conservation in the Okavango Delta, Botswana. Journal of Environmental Management, vol. 92, Page 1950-1959.

Sebele, L.S. 2010. Community-Based Tourism Ventures, Benefits and Challenges: Khama Rhino Sanctuary Trust, Central District, Botswana. Tourism management, vol. 31, no. 1, Page 136-146.

Suansri, P., Yeejaw-haw, S., and Richards, P. 2013. CBT standard handbook. Chiang Mai: The Thailand Communitybased Tourism Institute.

Sugiyono. 2011. Metode Penelitian Kuantitatif Kualitatif dan R\&D, 14th ed. Bandung: Alfabeta

Sunaryo, Bambang. 2013. Kebijakan Pembangunan Destinasi Pariwisata: Konsep dan Aplikasinya di Indonesia. 1.1. Yogyakarta: Gava Media. 